\title{
SSinteza
}

Impact of Internet on Business Activities in Serbia and Worldwide

Uticaj Interneta na poslovanje u Srbiji i svetu

DOI: 10.15308/SINTEZA-2014-816-820

\section{ISTRAŽIVANJE ŽIVOTNE SREDINE PRIMENOM GIS TEHNOLOGIJA I NJENIH INTERNET SERVISA}

\author{
Miloš Ninković \\ Fakultet za primenjenu ekologiju - Futura, Univerzitet Singidunum, Beograd
}

\begin{abstract}
:
Životna sredina, kao univerzalni kompleks procesa i pojava zahteva primenu raznih metoda istraživanja. Geografski informacioni sistemi, svojim neprastanim razvojem, naročito poslednje decenije, predstavljaju tehnologiju, kojom se pouzdano vrši detekcija, opisivanje i monitoring stanja životne sredine. Istraživanja mogu obuhvatiti pojedine medijume kao što su voda, vazduh, zemljište, flora i fauna ili skup svih fizičko-geografskih karakteristika prostora, kao i antropogene uticaje i efekte na životnu sredinu. GIS internet servisi su baze podataka raznih referentnih ustanova koje se bave proučavanjem svih pojava i procesa koji se odvijaju u prirodnoj sredini. Ovi servisi omogućavaju pristup različitim setovima podataka, koje korisnici mogu da preuzmu sa interneta. Glavna prednost ovih podataka je što obezbeđuju visok stepen preciznosti (merenja i snimanje terena), opsege od globalne do lokalne sredine i mogućnost posmatranja ispitivane pojave i procesa bez direktnog kontakta.
\end{abstract}

\section{Key words:}

GIS metoda,

Životna sredina,

GIS tehnologija,

GIS internet servisi.

\section{UVOD}

Proučavanje životne sredine i njena zaštita postaju sve neophodniji. Istraživanje životne sredine nije više stvar geografije, biologije ili uopšte nauka o Zemlji, već ono predstavalja predmet interesovanja niza fundamentalnih i primenjenih nauka, ali i praksa koje se danas primenjuju.

Životna sredina je prirodni okvir života u kome sva živa bića žive i deluju, mnogostruko povezana uzajamnim uticajima. To znači da pod pojmom životna sredina podrazumevamo prostor, okolinu u kojoj živa bića provode svoj život u stalnim međusobnim odnosima, sa svim unutrašnjim i spoljašnjim faktorima i uslovima koji daju i održavaju život.

Radom i drugim aktivnostima čovek i ljudsko društvo menjaju životnu sredinu. Svojim radnim aktivnostima ljudi su u prirodi ostavnli tragove. Ti tragovi sa razvojem ljudskog društva postaju sve značajniji i obimniji. Naročito su se desile velike promene sredinom 20-og veka, jer sa izgradnjom složenog i snažnog tehničko-tehnološkog sistema u ljudskim rukama su se našle snaga i energija neslućenog intenziteta tako da je čovek postao nezaobilazan menjajući faktor prirode. To je posebno izraženo u gije i sintetizovanih materijala. Destruktivno delovanje savremenog načina življenja sada već više milijardi ljudi na Zemlji, dovodi u pitanje opstanak globalnog geoekosistema, u kome mogu da nastupe takve promene koje će neumitno ugroziti opstanak čoveka na Zemlji.

Izučavanje uzajamnih veza i odnosa između prirode $i$ društva predstavlja složen teorijski i metodološki zadatak koji podrazumeva determinisanje uzročno-posledičnih veza u uzajamnom delovanju između prirodne sredine i društvenih potreba i aktivnosti.

Životna sredina, kao univerzalni kompleks procesa i pojava zahteva primenu raznih metoda istraživanja. Metode u ustraživanju životne sredine se dele u 4 velike grupe i to:

- Teorijske metode i postupci izučavanja životne sredine

- Posebne metode istraživanja životne sredine

- Metode evaluacije životne sredine

- Kartografski metod istraživanja životne sredine

Sa stanovišta primene geografskih informacionih sistema (GIS) u postupku istraživanja životne sredine, može se zaključiti da GIS sistemi u metodološkom smislu pripadaju svakoj od gore navedenih grupa metoda. Ovakav zaključak se nameće kao posledica kompleksnosti pri 
uspostavljanju, funkcionisanju i korišćenju GIS sistema u postupcima proučavanja životne sredine. GIS sistem je sposoban da pri uspostavi baze podataka vrši analizu, sintezu i klasifikaciju prostornih podataka i vrši njihovo modelovanje, što predstavlja osnovne teorijske metodološke pristupe. Sistem pomoću osnovnih alata za obradu i manipulaciju podataka, kao i dodatnim paketima alata posebne namene (alati za različite tipove modelovanja na primer: pojave i stepena razvoja erozije zemljišta, otapanje planinskih lednika, modelovanje hazardnih situacija i akcidenata, predviđanja i praćenja raznih pojava i procesa iz prirodne sredine itd.) obuhvataja aspekte posebnih metoda i metoda evaluacije životne sredine. To obogućava korisnicima GIS alata da opisuju trenutno stanje ispitivane pojave i procesa iz prirodnog okruženja. Na kraju kao izlazni podaci dobijaju se informacije za upotrebu o ispitivanoj pojavi ili procesu. Takve informacije mogu biti u vidu različitih tematskih karata, na osnovu kojih se GIS sistemi mogu svrstati u kartografske metode istraživanja životne sredine.

\section{GIS KAO METODA ISTRAŽIVANJA ŽIVOTNE SREDINE}

Ustanovljenje informiacionih sistema životne sredine je jedan od osnovnih preduslova, za rešavanje adekvatnog upravljanja životnom sredinom. Prikupljanje i obrada informacija o životnoj serdini je veoma složen posao jer podrazumeva njihovu akviziciju iz širokog kompleksa imalaca informacija i veoma različitog sklopa naučnih i stručnih oblasti, ali i iz različitih komponenti sredine koje ponekad mogu da budu izolovane jedna od druge iako one utiču jadna na drugu.

Primena informacione tehnologije je postala neophodna u domenu zaštite životne sredine, jer obezbeđuje neophodne informacije o životnoj sredini koje su odgovarajućeg nivoa detaljnosti, potpunosti, tačnosti i brzine. Ove informacije su podjednako značajne kao baza za odlučivanje o akcijama zaštite životne sredine kao i za sticanje znanja u istraživanju životne sredine. To uključuje opise trenutnog stanja životne sredine, prognoze budućeg razvoja životne sredine kao i ocenu trenutnog i budućeg stanja.

U obradi informacija životne sredine prisutni su sledeći ulazni i izlazni sadržaji:

- monitoring životne sredine sredstvima daljinske detekcije i kombinacijom podataka koji se prikupljaju sa svih strana sveta;

- deljenja i integracije informacija životne sredine duž političkih i administrativnih granica;

- napredne tehnike analize podataka bazirane na modelima se karakterišu prebacivanjem fokusa sa baza podataka na dinamičku strukturu sistema;

- način obrade informacija o životnoj sredini je sve detaljniji i obimniji, sa ciljem postizanja veće ekološke efikasnosti i ekonomskih sistema .

Savremeni GIS sistemi obrađuju informacije dobijene topografskim, aerofoto, satelitskim, radarskim i laserskim snimanjem.
Rad u GIS sistemu je baziran na unosu prikupljenih prostornih podataka, njihovoj obradi i grafičkoj prezentaciji. Svaki grafički elemenat u digitalnoj formi sadrži set osnovnih podataka, unetih kao njegovi atributi, na taj način stvarajući bazu podataka.

Od osnovnih podataka unose se: identifikacioni broj, oblik grafičkog prikaza (tačka, linija, poligon), ime objekta/lokaliteta, GPS (Global Positioning System) redni broj tačke, površina objekta/lokaliteta, nadmorska visina, geografske koordinate, slika objekta/lokaliteta, administrativna pripadnost lokaliteta itd. Ovo su osnovni parametri koji prate svaki elemanat u informacionom sistemu. Moguće je dodati niz drugih atributa elemntu, u zavisnosti od dostupnosti podataka

\section{GIS TEHNOLOGIJA}

GIS tehnologija je namenjena upravljanju prostorno orijentisanim podacima. Najveća vrednost ovih tehnologija je mogućnost analiza geografskih objekata i fenomena realnog sveta. Prostorne analize zasnivaju se na korišćenju raznih tehnika i metodologija (matematički algoritmi i funkcije, statističke funkcije, verovatnoće itd.).

GIS tehnologija integriše uobičajene operacije sa bazama podataka kao što su pretraživanja ,,upiti ili statističke analize,, sa jedinstvenim prednostima vizuelizacije i prostorne analize koju donose karte. Ove mogućnosti izdvajaju GIS od ostalih informacionih sistema i čine ga dragocenim alatom za najrazličitije namene i korisnike. Veliki broj događaja u našem okruženju ima prostornu komponentu ,informacije o prostoru odnosno mestu događanja.

Nije lako precizno definisati geografske informacione sisteme, jer će odgovora biti onoliko koliko ima i korisnika. Zbog toga je jednostavnije krenuti od tradicionalne definicije, ali uz stalno podsećanje na to da se uloga GIS-a tokom poslednjih godina neprestano menja.

Geografski informacioni sistem (GIS) je kompjuterski sistem za prikupljanje, obradu, prenos, arhiviranje i analizu podataka koji imaju i geografsku referencu. To je tehnička definicija, koja naglašava istorijski razvoj GIS-a kao kombinaciju projektovanja uz pomoć računara i mogućnosti rukovanja digitalnom kartografijom spojenom sa atributnim bazama podataka. Odnosno, može se reći da je GIS sistem za upravljanje prostornim podacima i njima pridruženim osobinama. U širem smislu GIS je oruđe „pametne karte" koje ostavlja mogućnost korisnicima da postavljaju interaktivne upite (istraživanja koja stvara korisnik), analiziraju prostorne informacije i uređuju podatke.

GIS je integrisani sistem koji ima višestruku ulogu u geoprostornim naukama, tehničkim naukama, ali i proučavanju i upravljanju životnom sredinom, pre svega:

- Predstavlja skup digitalnih i interaktivnih karata;

- Kompjuterski alat za rešavanje geoprostornih problema;

- Sistem za distribuciju geoprostornih informacija;

- Alat za analiziranje veza i odnosa među geoprostornim informacijama, koje se inače ne bi mogli lako uočiti. 
GIS se sastoji od četiri interaktivna podsistema:

- Podsistem za unos koji vrši konverziju karata (mapa) i drugih prostornih podataka u digitalni;

- Podsistem za skladištenje i pozivanje podataka;

- Podsistem za analizu

- Izlazni podsistem za izradu mapa, tabela i za pružanje odgovora na postavljene upite.

Tehnologija geografskog informacionog sistema može se koristiti za naučna istraživanja, upravljanje resursima, imovinsko upravljanje, planiranje razvoja, prostorno planiranje, kartografiju i planiranje infrastrukture. Mogu da ga koriste sve institucije i preduzeća koja se na bilo koji način bave prostorom, odnosno upravljanjem i eksploatacijom prostornih objekata.

Podaci za potrebe GIS-a dobijeni tehnologijama daljinske detekcije inkorporirani u odgovarajući geografski informacioni sistem predstavljaju ogromnu bazu podataka čija je primenljivost velika. Baza podataka formirana na ovakav način omogućava da svi podaci budu lako dostupni, proverljivi, integrisani, potpuni i kvalitetni. Primena metoda daljinske detekcije i inkorporacije u GIS je višestruka: pruža nam mogućnost sagledavanja velikih regionalnih površina, detaljne informacije o teško pristupačnim terenima, mogućnost sistematskog praćenja pojava i procesa od značaja i utvrđivanje potencijalnih zona ugroženosti prirodne sredine.

Geografski informacioni sistemi pružaju nam širok raspon mogućnosti analize i sinteze, koje se mogu upotrebljavati na različite načine. Analitičke mogućnosti formirane baze podataka organizovane su tako da se svaka vrsta anlize jednog parametra može izvesti ili zasebno ili u kombinaciji sa drugima parametrima. Mogućnosti sinteze su višestruke, a najadekvatnije je predstavljanje vizuelizacijom različitih vrsta digitalnih podatka, kao i mogućnost iznalaženja i primene različitih vrsta modela.

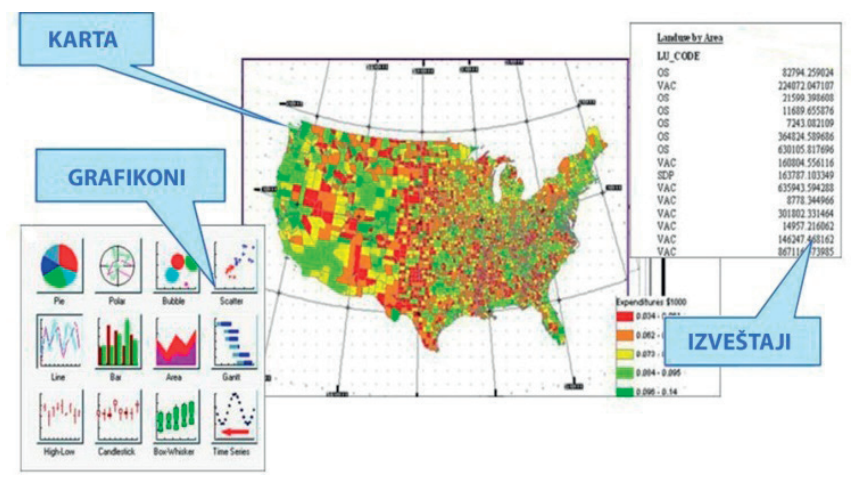

Slika 1. Načini prezentacije podataka u GIS sistemu kroz izveštaje (tabele), grafikone i tematske ili sintezne karte. Izvor:

http://www.google.rs/imgres (izmenjeno i dopunjeno).

GIS organizuje geografske podatke u tematske slojeve i tabele. Kako su geografski skupovi podataka u GIS-u georeferencirani, oni imaju realne lokacije i međusobno se preklapaju. Homogeni skupovi prostornih objekata su organizovani u slojeve kao što su parcele, izvori, zgrade, ortofoto snimci i raster digitalni modeli.

Za mnoge tipove geografskih operacija kao krajnji rezultat najbolja je vizuelizacija u obliku karata ili grafikona.
Karte su veoma efikasne za čuvanje i razmenu geografskih informacija. Mogu integrisati sa izveštajima, trodimenzionalnim pogledima, digitalnim fotografijama i ostalim digitalnim medijima.

Tabelarni podaci (baza podataka) u kombinaciji sa kartama (vizuelizacija prostora) predstavljaju suštinu daljinskih istraživanja životne sredine jer prikazuju parametre iz realnog prostora u digitalnom sistemu, predstavljenom grafičkim crtežima (tačke, linije, poligoni). Obradom ovih podataka dobija se informacija za upotrebu, na osnovu koje korisnici te informacije mogu donositi određene odluke na koji način upravljati životnom sredinom.

\section{GIS INTERNET SERVISI}

Mogućnosti Interneta i njegova primena u GIS tehnologijama se svakim danom povećava. Internet je jednostavan za upotrebu i relativno jeftin način pristupa izvoru neograničenog broja informacija i materijala za potrebe izrade GIS projekata. Sve je veći broj institucija, projektnih, istraživačkih i naučnih, koje koriste GIS u internet okruženju. Internet, sa svojim servisima koje pruža, objedinjuje multimedijalne i komunikacione tehnologije, pomoću kojih jednostavno vrši distribuciju i obradu GIS podataka.

GIS internet servis se može definisati kao mreža geografskih informacionih usluga za pristup i distribuciju geografskim informacijama, primenu prostorno-analitičkih alata, kao i online obradu GIS podataka. Osnovni koncept Web GIS-a je glavna promena paradigme od tradicionalne primene desktop GIS modela ka slobodnoj razmeni podataka. Desktop GIS model je podsticao korišćenje i razvoj vlasničkih i sveobuhvatnih GIS softverskih programa i modela podataka. Internet GIS servisi obezbeđuju slobodu u preuzimanju, deljenju i obradi podataka, omogućavaju besplatne softverske aplikacije i mogućnost skladištenja podataka na zakupljenom GIS serveru. Ova promena je izmenila pejzaž GIS-a da se podstakne rast mnogih malih Internet provajdera usluga i GIS-specijalizovanih usluga.

Internet GIS servisi obuhvataju širok spektar aplikacija i servera koji uključuju korišćenje kombinovanih digitalnih mapa i georeferenciranih podataka o prirodnoj sredini. Serveri predstavljaju privatnu svojinu ili su pod zakupom naučnih ustanova (fakulteta, kao što je MapServer - University of Minnesota), istraživačkih organizacija (CGIAR-CSI Server - Konsultativna grupa za međunarodna poljoprivredna istraživanja - konzorcijum za prostorna istraživanja - CGIAR - CSI - Consultative Group on International Agricultural Research - Consortium for Spatial Information).

ArcGIS Server je jezgro servera geografskih informacionih sistema. Omogućava punu podršku raznih dodatnih alata i podataka matičnom ArcMap softverskom paketu, koji predstavlja lidera u oblasti aplikativnih GIS programa kreiran i razvijan od strane ESRI kompanije.

Server se koristi za kreiranje i upravljanje GIS Veb servisa, aplikacija i podatka. Tipične aplikacije ArcGIS Servera koje klijenti mogu da koriste su mapiranje, usluge pro- 
storne analize u geoportalima i infrastrukture prostornih podataka. Mogućnost pristupa onlajn prodavnicama i Veb portalima međunarodnih istraživačkih organizacija (kao što je Nacionalna uprava za okeane i atmosferu - National Oceanic and Atmospheric Administration - NOAA), onlajn praćenje vremenskih prilika, kretanje resursa, razmenu naučnih istraživanja i modelovanja, upravljanje i isporuka podataka daljinske detekcije, kao i prikupljanje podataka korišćenjem mobilnih uređaja i sistema globalnog pozicioniranja (GPS).

Nasuprot ArcGIS Serveru, postoji Quantum GIS (QGIS) server sa svojim slobodnim "open source" geografskim informacionim sistemom, koji omogućava podršku matičnom softveru i pristup raznim GIS podacima tzv. setovima podataka (data sets). To je besplatna open source platforma za desktop geografski informacioni sistem (GIS).

Aplikacija koja obezbeđuje podatke za gledanje, editovanje, i prostorne analize zove se Quantum GIS Valmeria 2.2. (trenutno poslednja aktuelna verzija QGIS-a). Ovaj program omogućava korisnicima da kreiraju mape sa mnogo slojeva koristeći različite geografske projekcije. Karte mogu da se eksportuju u različitim formatima i za različite namene. Softver podržava alate da se različite vrste rasterskih slika mogu podvrgnuti postupku georeferenciranja (ubacivanje slika u validni koordinatni sistem). QGIS omogućava integraciju sa drugim open source GIS paketima, uključujući PostGIS, Grass, i MapServer koji daju korisnicima široku funkcionalnost i mogućnost importovanja podataka preuzetih sa ovih serverskih stanica.

SuperGIS server, sveobuhvatan GIS server dizajniran da omogući klijentima da sami kreiraju, upravljaju, integrišu i distribuiraju različite GIS podatke, kao što su mape, globusi, setovi geopodataka, alata, itd; preko Interneta, kao podrška desktop, mobilnim i veb aplikacijama. SuperGIS server omogućava klijentima da beskonačno dele najsavremenije GIS resurse širom preduzeća i širom Veba.

SuperGIS server efikasno pojednostavljuje proces pristupanja GIS bazama podataka, GIS stručnjacima, terenskim radnicima i radnicima bez ikakvog iskustva u GIS tehnologiji. Sa SuperGIS Serverom, klijenti mogu značajno smanjiti troškove skladištenja podataka, kupovine softvera, kao i teret obrade podataka.

Postoji mnoštvo GIS alata koji se oslanjaju na onlajn izvore informacija kao što je GlobalMapper. Ovaj softverski paket koristi direktnu vezu sa raznim GIS serverima kako bi prikazao njihove sadržaje korisniku. Takvi sadržaji su podaci u rasterskom obliku i oni se ne mogu menjati, već služe korisniku za dobijanje informacija o prostoru. Program koristi izvore kao što su mape ulica - OpenStreetMap za prikaz saobraćajne infrastrukture, za prikaz reljefa terena elevacioni model - SRTM (The Shuttle Radar Topography Mission) worldwide elevation data, za prikaz satelitskih snimaka koriste se slike sa satelita Landsat7 Global Imageri Mosaic i razni drugi izvori.

\section{PRIMENA GIS INTERNET SERVISA}

Primena nekog GIS internet servisa, zavisi od potrebe i vrste istraživanja, koja diktira neophodnost konkretizacije podataka koji će se koristiti. U zavisnosti od oblasti koja se proučava u prirodnoj sredini, bilo da je voda, vazduh, zemljište, određeni prirodni resurs ili akcidentna pojava u prirodi, koriste se internet izvori samo za tu oblast.

Primenu GIS internet servisa u konkretnom postup$\mathrm{ku}$ istraživanja i prikupljanja podataka prikazujem u daljem tekstu na primeru opštine Ljubovija. Za potrebe izrade GIS baze podataka opštine Ljubovija, korišćeno je nekoliko GIS intetnet servisa. Jedan od takvih je SRTM Worldwide Elevation Data (3-arc second Resolution) $\mathrm{http} /$ srtm.csi.cgair.org, radi prikupljanja podataka o reljefu i hipsometrijskim karakteristikama opštine Lubovija. Priustup ovom “open source” portalu izvršen je preko programa Global Mapper 11. Podaci koji su preuzeti sa ovog GIS internet servisa su rasterska slika i vektorski podatak (shapefile). Rasterska slika je preuzeta u koloru (u atlas shader- tehnici nijansiranja boja visinskih zona po uzoru na geografske atlase). Ovakva rasterska slika prikazuje karakteristike reljefa, najviše vrhove, najniže delove opštine, rečne doline, ekspozicije terena itd. Moguće je izvršiti dodatnu obradu rastera u programu i napraviti 3D prikaz reljefa (simulaciju), kroz koju je moguće kretanje po terenu. Raster se može sačuvati kao GeoTiff ekstenzija, koja je prenosiva u druge programe i GIS baze. Vektorski podatak (shapefile) predstavlja generisane izolinije, koje poseduju vrednosti odgovarajuće nadmorske visine - izohipse. Ove linije su takođe generisane u Global Mapper$\mathrm{u}$, a u zavisnosti od potrebe, stepen detaljnosti podataka (izohipsi) koje se generišu mogu biti sa velikom ili malom ekvidistancom (visinskom razlikom između dve izohipse). Što je ekvidistanca veća broj izohipsi će biti manji i obrnuto (obično se uzima ekvidistanca od 40,60 ili 80 metara za planinske terene i od 5, 10 ili 20 metara za ravničarske terene).

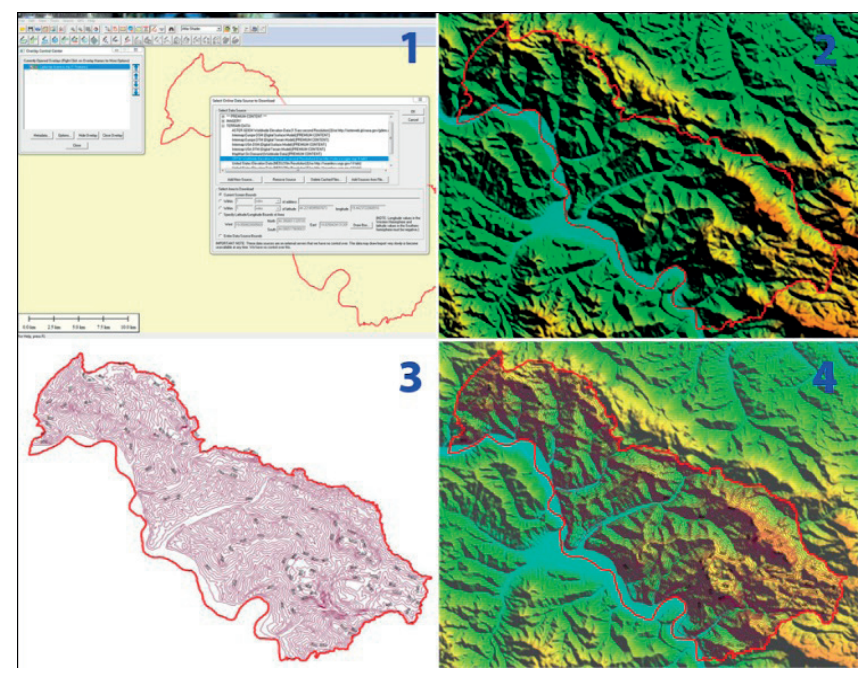

Slika 2. Prikaz preuzimanja podataka izborom GIS internet servisa (1), preuzeta rasterska slika (2), generisani vektorski podaci (3) i kombinacija rasterskih i vektorskih podataka (4). Izvor: Global Mapper 11, SRTM Worldwide Elevation Data (3-arc second Resolution)-http//srtm.csi.cgair.org (izmenjeno i dopunjeno).

Vektorski podatak za razliku od rasterskog podatka je izmenjiv. Moguće je vršiti eventualne korekcije, menjati položaj, dužinu izohipsi, spajati dve izohipse istih vredno- 
sti, deliti izohipsu na više manjih itd. Vektorski podatak je sačuvan u univerzalnoj GIS ekstenziji (.shp-shapefile) i kao takav može se učitavati u druge programe i GIS baze podataka.

Rastersku sliku i vektorske izolinije (izohipse), je moguće prikazivati kao zasebne podatke, a takođe je moguća i njihova međusobna kombinacija u prezentovanju. Moguće je ove podatke kombinovati i sa drugim vektorskim podacima kao što bi to bila hidrografska mreža sa prikazom reljefa.

Pomoću ove dve vrste podataka (rasterskog i vektorskog), preuzetih sa GIS internet servisa, neuporedivo se brže i jednostavnije dobijaju informacije o karakteristikama reljefa opštine Ljubovija. Stara metoda za dobijanje ovakvih informacija bi podrazumevala georeferenciranje stare geografske ili orografske karte, zatim postupak precrtavanja sadržaja sa tih karata (digitalizacija) što je vremenski izuzetno dug i naporan posao.

Zato savremene tehnologije koje ispunjavaju potrebu za dobijanjem brzih, tačnih i proverenih informacija neprestano razvijaju GIS internert servise i na taj način omogućuju korisnicima širom sveta lak pristup željenim podacima.

\section{ZAKLJUČAK}

U cilju optimalnog korišćenja GIS-a, nije dovoljno da korisnik samo nabavi odgovarajući hardver, softver i ljude koji će raditi na sistemu, već i da sistem bude adekvatno organizaciono postavljen, a ljudi koji rade na sistemu da poseduju osnovna geografska i kartografska znanja. Danas, posle nekoliko decenija razvoja, GIS je dokazao svoje prednosti u svim oblastima gde se zahteva vizuelizacija prostornih podataka i manipulisanje velikim brojem podataka, koji su opisani vrlo složenim konceptima i imaju veliki broj korisnika raznih struka. GIS tehnologija omogućava veliki napredak u svim oblastima i procesima upravljanja, praćenja, organizacije i odlučivanja u odnosu na konvencionalne metode rada.

Razvoj GIS alata i njihova implementacija na serverske stanice i umrrežavanje na Internet mrežu, doprinosi vrtoglavom rastu informacija i podataka o planeti Zemlji. Glavna prednost GIS internet servisa je brza i jednostavna dostupnost ovih podataka, koja može biti na globalnom nivou cele Zemlje ili na nivou neke lokalne regije, u zavisnosti od potreba korisnika. Neki od servisa su besplatni i bez ograničenja na pristup informacijama, dok neki uz odrđenu novčanu nadoknadu obezbeđuju čitave projekte sortirane u raznim setovima podataka.

Dalji razvoj GIS sistema prebaciće težište na ujedinjenje svih GIS serverskih stanica i objedinjavanje svih prostornih podataka na jednom mestu. Ovakav postupak će znatno uštedeti vreme pretrage neophodnih informacija i podataka korisnicima. Takođe sve više će se ostvarivati otvorene baze podataka gde će svako moći da doprinese u daljem razvoju i širenju GIS baza (slično kao Vikipedija gde svako može da uređuje članke). Iz ovoga se zaključuje da će GIS tehnologije postati javno dobro, koje će omogućiti brži i bolji rad sa prostornim podacima, njihovo skladištenje i čuvanje i delovanje u donošenju bitnih odluka vezanih za prostor i životnu sredinu.

U cilju upravljanja prirodnim resursima na održiv način, potrebna je tačna i pravovremena informacija da bi se blagovremeno odregovalo na promene u prostoru. Iz tog razloga, potrebno je formirati sistem koji će objediniti sve relevantne podatke radi postizanja zadatog cilja. Neophodno je izvršiti konverziju i modifikaciju postojećih podataka, izvršiti digitalizaciju i integrisati ih u jedinstvenu bazu podataka. Radi postizanja navedenih zahteva nameće se jednostavan odgovor - primena geografskog informacionog sistema.

\section{LITERATURA}

[1] Bill, R., (1995): Spatial Data Processing in environmental Information Systems, , in: "Environmental Informatics Methodology and Applications of Environmental Processing, Kluwer Academic Publichers, Dordrecht.

[2] Burrough, P.A. and McDonnell, R.A. (1998) Principles of geographical information systems. Oxford University Press, Oxford, 327 pp.

[3] Čekerevac Z., Anđelić S., Glumac S., Dragović N., Savremene tendencije primene GIS tehnologija, Međunarodna naučna konferencija Menadžment 2010, Kruševac, Srbija, 17-18. mart 2010.

[4] Đukanović M., (1991): Ekološki izazov, Elite, Beograd

[5] Hilty, L.M., Page, B., Radermacher F.J., Riekert W.F., (1995): Environmental Informatics as a new Discipline of Applied Computer Science, in: "Environmental Informatics - Methodology and Aplications of Environmental Procesing, Kluwer Academic Publichers, Dordrecht.

[6] Lješević M., (2010): Životna sredina teorija i metodologija istraživanja, Univerzitet Singidunum, Fakultet za primenjenu ekologiju Futura, NVO EKORIZIK, Beograd.

[7] Martijn van Leusen P., (1993): Cartographic modelling in a cell-based GIS, Computing the Past. Computer Applications and Quantitative Methods in Archaeology. CAA92. J. Andersen, T. Madsen \& I. Scollar, pp.105-123. Aarhus University Press. Oxford (1993).

[8] Nebert, Douglas D., (1995): Serving digital map information trough the World Wide Web and wide-area information server technologz. Reston, U.S. Geological Survey.

[9] Pavlović D., (2010): Geografski informacioni sistem (GIS)Uloga i značaj implementacije u nacionalnom parku Đerdap, JP “Nacionalni park Đerdap" - Donji Milanovac.

[10] Page, B,. (1995): Environmental Informatics Towards a new Discipline in Applied Computer Science for Environmental Protection and Research, "Environmental Software Systems", Chapman \& Hall, London.

[11] Peng, Zhong-Ren, Ming-Hsiang T. (2003): Internet GIS: Distributed geographic information services for the Internet and wireless networks. Hoboken, N.J., John Wilez \& Sons. 